\author{
(1) Khin Zar Li Aung, \\ (1) Rabia Yılmaz, \\ (1) Ezgi Güngördü, \\ (1) Sinan Aşar, \\ (D) Yasemin Tekdos Şeker
}

Received/Geliş Tarihi : 11.05.2021

Accepted/Kabul Tarihi : 08.12.2021

${ }^{\circ}$ Copyright 2021 by Turkish Society of Intensive Care Turkish Journal of Intensive Care published by Galenos Publishing House.

\section{Does Favipiravir Reduce Mortality in Patients with COVID-19 ARDS and Severe Pneumonia?}

\author{
COVID-19 ARDS ve Ağır COVID Pnömonisi \\ Hastalarında Favipiravir Mortaliteyi Azaltır Mı?
}

Khin Zar Li Aung, Rabia Yılmaz, Ezgi Güngördü, Sinan Așar, Yasemin Tekdos Seker

University of Health Sciences Turkey, Istanbul Bakırköy Dr. Sadi Konuk Research and Training Hospital, Intensive Care Unit, Istanbul, Turkey

Rabia Yılmaz MD, $(\bowtie)$,

University of Health Sciences Turkey, Istanbul Bakırköy Dr. Sadi Konuk Research and Training Hospital, Intensive Care Unit, Istanbul, Turkey

E-mail : drrabiayilmaz@gmail.com

Phone : : +90539840 2719

ORCID ID : orcid.org/0000-0003-1707-4607
ABSTRACT Objective: Although there is no antiviral treatment specific to the virus, favipiravir has entered the treatment routine as an antiviral in our country in May 2020. In this study, in patients with severe acute respiratory syndrome coronavirus 2 (SARS-CoV-2) acute respiratory distress syndrome (ARDS) in the intensive care unit; The effects of favipiravir antiviral regimen on mortality and morbidity were evaluated.

Materials and Methods: Patients admitted to the intensive care unit were divided into two groups as those who received favipiravir (group $F ; n=208$ ) and those who did not (group $N ; n=101$ ). The treatment of the cases is arranged according to current national guidelines. Metavision/QlinICU Clinical Decision Support Software, in intensive care unit; Acute Physiology and Chronic Health Evaluation-II, Sequential Organ Failure Assessment score, aspartate aminotransferase, alanine aminotransferase, urea, creatinine, lactate dehydrogenase, ferritin, C-reactive protein (CRP), procalcitonin, Pro-BNP, D-dimer, fibrinogen, white blood cell, neutrophil count (NEU), lymphocyte count (LYM), NEU/LYM, CRP, t1 acceptance ( $0^{\text {th }}$ hour), t2 follow-up ( $24^{\text {th }}$ hour) and $\mathrm{t} 3$ (discharge or ex) values of acute phase parameters, and the comorbidity is obtained by Structured Query Language queries. The primary outcome is mortality; secondary outcomes are possible drugrelated organ toxicities, sudden change of the level of the acute phase reactants, requirement of continuous renal replacement therapy (CRRT), hospitalization time, ventilator dependent days. Results: One hundred eight women (35\%), 201 men (65\%), a total of 309 cases were evaluated in the study. In the demographic data of the groups, no statistically significant difference was found between the frequency of comorbidity, mortality rate, CRRT need, and secondary infection. The mean increase of $107.66 \pm 628.99$ units between the $t 1$ and $t 3$ measurement was found to be statistically significant in $\mathrm{F}$ group cases. In the $\mathrm{F}$ group, the neutrophil/lymphocyte ratio (NLR) during the follow-up period and the last NLR were found to be lower than the initial value.

Conclusion: It was determined that favipiravir used in the treatment of SARS-CoV-2 ARDS has no superiority in preventing mortality.

Keywords: Favipiravir, COVID-19, ARDS, mortality

ÖZ Amaç: Virüse özgü antiviral tedavi olmamakla birlikte, favipiravir Mayıs 2020'de ülkemizde antiviral olarak tedavi rutinine girmiştir. Bu çalışmada yoğun bakım ünitesinde şiddetli akut solunum sendromu koronavirüs 2 (SARS-CoV-2) akut solunum sıkıntısı sendromlu (ARDS) hastalarda favipiravir antiviral rejiminin mortalite ve morbidite üzerindeki etkileri değerlendirildi.

Gereç ve Yöntem: Yoğun bakım ünitesine kabul edilen hastalar, favipiravir alanlar (grup F; $n=208$ ) ve almayanlar (grup N; $n=101$ ) olarak iki gruba ayrıldı. Olguların tedavisi güncel ulusal kılavuzlara göre düzenlendi. Metavision/QlinıCU Yoğun Bakım Ünitesi'nde Klinik Karar Destek Yazılımı; Akut Fizyoloji ve Kronik Sağlık Değerlendirmesi-II, komorbidite, Sıralı Organ Yetmezliği Değerlendirmesi skoru, aspartat aminotransferaz, alanin aminotransferaz, üre, kreatinin, laktat dehidrogenaz, ferritin, C-reaktif protein (CRP), prokalsitonin, Pro-BNP, D-dimer, fibrinojen, beyaz kan hücresi, nötrofil sayıSı (NEU), lenfosit sayısı (LYM), NEU/LYM, CRP, t1 kabulü (0. saat), akut faz parametrelerinin t2 takip (24. saat) ve t3 (taburcu veya eks) değerleri, Yapısal Sorgulama Dili (Structured Query Language) sorguları ile elde edilir. Birincil sonuç mortalitedir; ikincil sonuçlar, ilaca bağlı olası organ toksisiteleri, akut faz reaktanlarının seviyesinde ani değişiklik, sürekli renal replasman tedavisi (CRRT) gereksinimi, hastanede kalış süresi, ventilatöre bağlı günlerdir.

Bulgular: Çalışmada 108 kadın (\%35), 201 erkek (\%65), toplam 309 olgu değerlendirildi. Grupların demografik verilerinde komorbidite sıklığı, mortalite oranı, CRRT intiyacı ve sekonder enfeksiyon arasında istatistiksel olarak anlamlı fark bulunmadı. F grubu olgularda t1 ve t3 ölçümleri arasında $107,66 \pm 628,99$ birimlik ortalama artış istatistiksel olarak anlamlı bulundu. F grubunda takip süresince nötrofil/lenfosit oranı (NLO) ve son NLO başlangıç değerinden düşük bulundu. Sonuç: SARS-CoV-2 ARDS tedavisinde kullanılan favipiravirin mortaliteyi önlemede üstünlüğü olmadığı belirlendi.

Anahtar Kelimeler: Favipiravir, COVID-19, ARDS, mortalite 


\section{Introduction}

Currently, there isn't any precise effective antiviral treatment specific to the severe acute respiratory syndrome coronavirus 2 (SARS-CoV-2) virus that causes coronavirus disease-2019 (COVID-19) disease (1). Since there is no known specific antiviral treatment, generic antiviral agents such as remdesivir, hydroxychloroquine and chloroquine, favipiravir, lopinavir-ritonavir (lop/r), umifenovir, and ribavirin are used in the management of the disease (2). In our country, Hydroxychloroquine and/or favipiravir are still recommended in the Treatment Guide for Adult Patients with COVID-19 created by the Scientific Committee (latest update 29/06/2021) (3) and these drugs are routinely used in all patients.

Favipiravir is a new type of drug that is a RNA dependent RNA polymerase inhibitor. Therefore, favipiravir may have potential antiviral effect on SARS-CoV-2, an RNA virus (4). In a clinical study conducted in China which favipiravir and lop/r were compared shows that favipiravir has stronger antiviral activity (5).

Several scoring methods such as Sequential Organ Failure Assessment (SOFA) score and Acute Physiology and Health Assessment-II (APACHE-II) score are used in intensive care units (ICU) for mortality prediction; some biomarkers are also used for this purpose. Factors such as advanced age ( $\geq 65$ years of age), accompanying comorbidities, high fever $\left(>39^{\circ} \mathrm{C}\right.$ ), lymphopenia, neutrophilia, C-reactive protein (CRP) level, serum ferritin level, coagulation parameters (D-dimer and prothrombin time) have been shown to increase the risk of severe pneumonia and developing of acute respiratory distress syndrome (ARDS) (6).

The COVID-19 pandemic is a health problem that affects the whole world and the antiviral treatments used in the treatment of the disease are still being updated. As in our country, favipiravir is recommended in treatment guidelines in many countries and it is routinely used for many patients. In this study, we aimed to reveal the effects of favipiravir as an antiviral regimen used in the treatment of patients with severe pneumonia and ARDS associated with COVID-19 on mortality and morbidity in the ICU.

\section{Materials and Methods}

After the approval of the Turkish Ministry of Health Clinical Research Board; our study was approved by the Local Ethics Committee of the Bakırköy Dr. Sadi Konuk
Training and Research Hospital with the decision number 2020/389 (date: 07.09.2020).

The treatment of patients with severe pneumonia and ARDS associated with COVID-19 admitted to Health Sciences University Turkey Bakırköy Dr Sadi Konuk Training and Research Hospital Anesthesiology and Reanimation Department ICU are reviewed observationally and retrospectively between 15 March 2020 and 29 November 2020 in this study. We examined 208 patients who had favipiravir in their treatment regimen (named as group $\mathrm{F}$ ) ( $2 \times 1,600 \mathrm{mg}$ at first day as a loading dose, followed by $2 \times 600$ mg per day in next 4-9 days, 5-10 days treatment in total) and 101 patients who had not favipiravir in their treatment regimen (named as group $\mathrm{N}$ ).

According to the current guideline (7); the patients infected by SARS-CoV-2 were diagnosed with polymerase chain reaction (PCR) test in the first line. The diagnosis was determined in PCR negative patients through positive chest computed tomography scan or/with lower respiratory tract infection findings such as fever, cough, dyspnea.

Severe pneumonia was described according to the Surviving Sepsis Campaign Guidelines on the Management of Adults with COVID-19 (7), and ARDS was described according to the Berlin criteria (8).

The study was planned as a retrospective observational study on the systemic effects of antiviral treatment before and after updates in the Treatment Guide for Adult Patients with COVID-19 compiled by the Ministry of Health's General Directorate of Public Health. Standardized supportive treatments were applied to both groups of patients; such as antibiotic therapy directed to the source in the presence of secondary infection, sedation agents, nutritional support, cardiovascular support therapy, steroids, immunomodulatory drugs, non-invasive positive pressure ventilation or invasive ventilation therapy, continuous renal replacement therapy (CRRT), extracorporeal membrane oxygenation treatment for patients whom conventional mechanical ventilation support is insufficient for. Since both groups were followed by the same intensive care team and with the same treatment protocol, we think that there is no obvious difference in terms of supportive treatments.

Cases with procalcitonin level $>1$ during follow-up were considered to be accompanied by secondary infection.

Patients younger than 18 years old, patients were followed for less than 24 hours in ICU, patients were pregnant or breastfeeding, patients whose treatment 
was interrupted due to drug side effects were excluded from the study. We determined the primary outcome as mortality and secondary outcomes as possible drug-related organ toxicities, sudden change of the level of the acute phase reactants, requirement of CRRT, hospitalization time, ventilator dependent days.

Demographic data of patients diagnosed with COVID-19 pneumonia or ARDS in the Anesthesiology and reanimation intensive care unit registered in 'ImdSoft-Metavision/QlinICU Clinical Decision Support Software'. APACHE-II, SOFA score, level of aspartate aminotransferase (AST), alanine aminotransferase (ALT), urea, creatinine, lactate dehydrogenase $(\mathrm{LDH})$, ferritin, CRP, procalcitonin, Pro-BNP, D-dimer, fibrinogen, white blood cell (WBC), neutrophil count (NEU), lymphocyte count (LYM), NEU/LYM ratio, acute phase parameters at admission $\left(0^{\text {th }}\right.$ hour), at follow-up (24 $4^{\text {th }}$ hour) and at discharge or time of death is obtained by Structured Query Language queries. Admission time is defined as $\mathrm{t} 1,24^{\text {th }}$ hour of follow up defined as $\mathrm{t} 2$, and discharge or exitus time defined as $\mathrm{t} 3$. The presence of secondary infection was decided through procalcitonin level $>1$ during follow-up.

\section{Statistical Analysis}

The Number Cruncher Statistical System program was used for statistical analysis. Descriptive statistical methods (to identify the mean, standard deviation, median, frequency, percentage, minimum value, maximum value) were used for evaluating the study data. The suitability of quantitative data to normal distribution was tested by Shapiro-Wilk test and graphical analysis. Studen t-test was used for comparing parametric quantitative variables between two groups. T-test and Mann-Whitney $U$ test were used to compare non-parametric quantitative variables to analyze quantitative independent data. Paired samples test was used for ingroup comparisons of quantitative variables with normal distribution. The Wilcoxon signed-rank test was used for ingroup comparisons of non parametric quantitative variables and for analysis of dependent quantitative data. Pearson chi-square test and Fisher-Freeman-Halton Exact test were used to analyze and compare qualitative independent data. The distribution of variables is measured by the Kolmogorov-Smirnov test. The SPSS 27.0 program was used in the analyzes. Statistical significance was accepted as $p<0.05$.

\section{Results}

Of the patients participating in the study, $35 \%(n=108)$ were female and $65 \%(n=201)$ were male. The ages of the cases ranged from 18 to 100 , and the mean value was $60.29 \pm 16.56$ years. There was no statistically significant difference in terms of age, height, weight and gender distributions between the two groups. Total mortality rate was $48.5 \%$, and there was no statistically significant difference between the mortality rates between group $F(48.6 \%)$ and group N (48.5\%). There was no statistically significant difference between the groups in terms of secondary outcomes, comorbidities, the presence of secondary infection and horowitz index at the time of admission to intensive care unit (t1). There was no statistically significant difference in APACHE-II and SOFA scores between the groups at $\mathrm{t} 1$. The ratio of the intubated patients was similar in both groups $(p<0.05)$ (Table 1).

The increases in AST level between $\mathrm{t} 1$ and $\mathrm{t} 2$, by an average of $99.23 \pm 1294.29$ units and between $t 1$ and $t 3$, by an average of $446.75 \pm 1868.19$ units were found to be statistically significant $(p=0.014 ; p=0.005)$. The difference between AST level between at $\mathrm{t} 1$ and $\mathrm{t} 2$ in $\mathrm{F}$ group cases was found to be statistically significantly higher than the group $N$ cases $(p=0.039$ ).

The mean increase of ALT level from t1 to $t 3$ is $107.66 \pm 628.99$ units, it was found to be statistically significant in $F$ group cases $(p=0.001)$. The transaminase levels of the groups are shown in Table 2 .

The urea and creatinine levels of the cases do not show statistically significant differences depending on the groups ( $p>0.05)$.

Acute phase physiological parameters such as CRP, ferritin, LDH, D-dimer, procalcitonin, and fibrinogen levels were evaluated. There was no difference between the groups in the follow-up process. Hemogram parameters were evaluated, no significant difference was observed in WBC levels at $\mathrm{t} 1, \mathrm{t} 2$ and $\mathrm{t} 3$ times in group $\mathrm{F}$ and group $\mathrm{N}$ cases. No significant difference was observed in the lymphocyte levels between group $\mathrm{F}$ and group N. A significant increase was found in the lymphocyte levels at $\mathrm{t} 3$ of both groups compared to the initial measurement $(t 1)(p<0.05)$. In the $F$ group, the neutrophil/lymphocyte ratio (NLR) during the follow-up period and the last NLR were found to be lower than the initial value $(p<0.05)$ (Table 3$)$. 


\section{Discussion}

Favipiravir was reported to be particularly useful in the treatment of mild to moderate disease with its safety and efficacy profile $(9,10)$. Unlike these studies, our patients were critically ill patients and we didn't determine any difference in mortality.

Clinical trials of COVID-19 infection in China suggest that favipiravir has a faster viral clearance than lop/r and better recovery rate than umifenovir and has a positive effect on morbidity and mortality $(10,11)$. Favipiravir + INF inhalation and $\mathrm{lop} / \mathrm{r}+\mathrm{INF}$ inhalation treatment was compared in a total of 80 COVID-19 patients in a study conducted by Chen et al. (11). It was shown that the favipiravir group has shorter viral clearance time (4 days, 11 days) and better radiological recovery rate $(91.4 \%, 62.2 \%)$ compared to the other group in this study. The frequency of side effects was also found to be less in the favipiravir group. Contrary to these literature, no reduction in mortality was observed in patients receiving favipiravir in our study.

In a randomized clinical study in China comparing favipiravir and umifenovir as antiviral therapy, recovery rates on the seventh day of the treatment were examined, no significant difference was found between these two

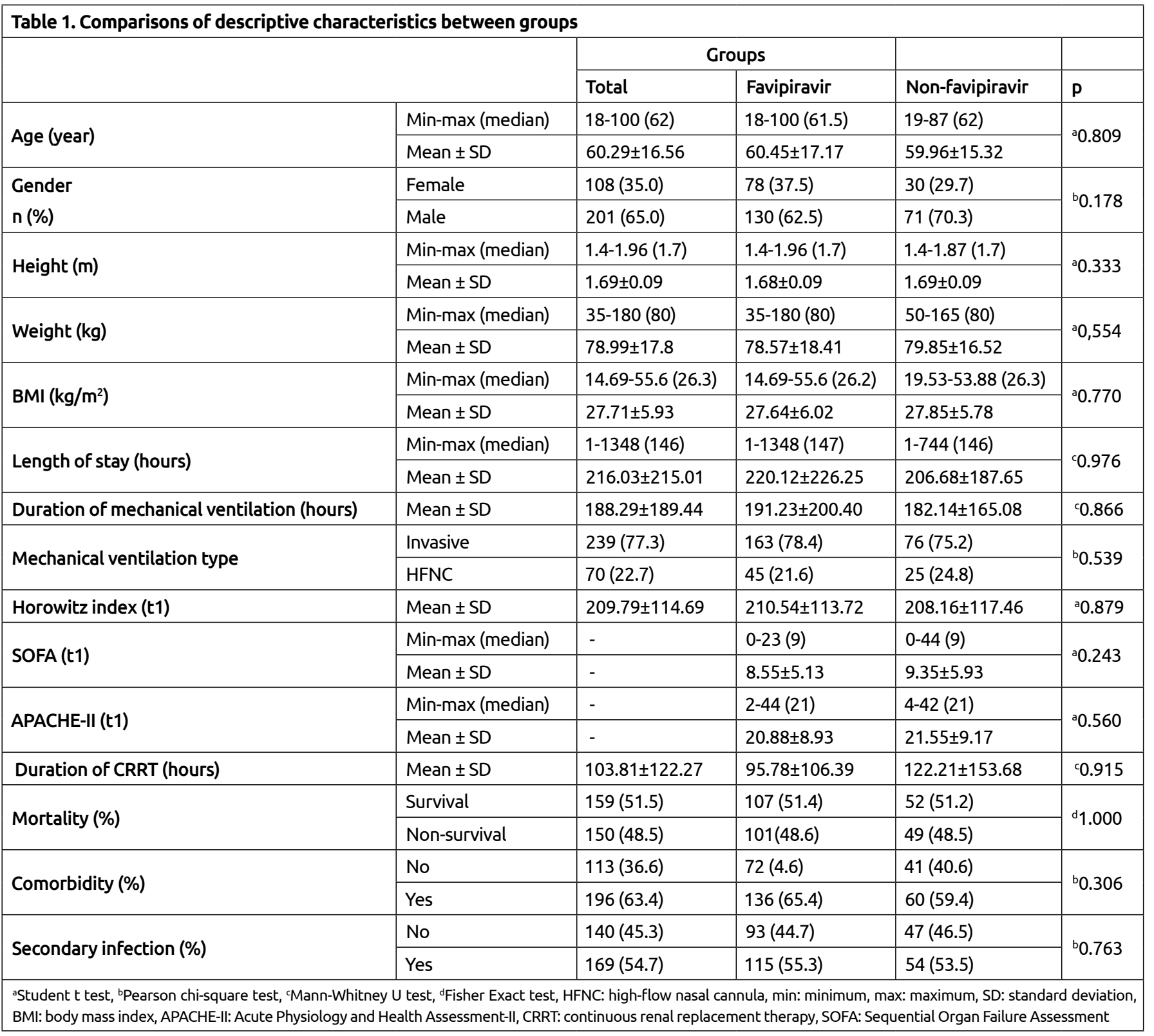


drugs (11). Ribavirin + corticosteroid as a standard treatment in newly diagnosed SARS-CoV-1 patients and lop/ $r$ + ribavirin + corticosteroid treatment was compared by Chan et al. (10). at the time of the SARS-CoV-1 epidemic. A statistically significant difference was found in terms of mortality and ARDS development on the $21^{\text {st }}$ day in this study.

In a randomized controlled trial including 199 COVID-19 cases, patients received standard care (SC) + lop/r or only $\mathrm{SC}$ were compared. It was stated that lop $/ \mathrm{r}+\mathrm{SC}$ was not different from SC in terms of time of clinical recovery and mortality in 28 days. (lop/r + SC 19.2\%, SC 25\%). The authors stated that lop/r does not contribute to SC in the treatment of patients infected by COVID-19. They stated that although mortality was reported as $11-14.5 \%$ in patients hospitalized due to COVID-19, the high rate of mortality $22.1 \%$ in this study might be due to the fact that the patients included in the study were severe patients (12).

Our study was conducted in patients followed-up in intensive care. Total mortality is $48.5 \%$, and there is no significant difference between the groups.

Favipiravir has a well-characterized safety profile over 4,000 patients. Similar rates of side effects have been reported between low and high doses of favipiravir. Gastrointestinal side effects, increased uric acid levels, decreased neutrophil count, increased AST and ALT levels, psychiatric symptom reactions, and increased blood lipid profile are among the common side effects. The rates of serious side effects are $0.4 \%$ and $1.1 \%$ (13). Use of favipiravir in patients with moderate renal impairment

\begin{tabular}{|c|c|c|c|c|}
\hline & & \multicolumn{2}{|c|}{ Groups } & \multirow[b]{2}{*}{ p } \\
\hline & & Favipiravir & Non-favipiravir & \\
\hline \multirow{2}{*}{$\begin{array}{l}\text { AST level (t1) } \\
(\mathrm{U} / \mathrm{L})\end{array}$} & Min-max (median) & 9-5884 (49.5) & $12-6,106(60)$ & \multirow{2}{*}{${ }^{c} 0.047^{*}$} \\
\hline & Mean \pm SD & $164.82 \pm 574.03$ & $200.12 \pm 668.64$ & \\
\hline \multirow{2}{*}{$\begin{array}{l}\text { AST level (t2) } \\
\text { (U/L) }\end{array}$} & Min-max (median) & $8-15,026(40)$ & $12-9,282(40)$ & \multirow{2}{*}{${ }^{\circ} 0.338$} \\
\hline & Mean \pm SD & $264.05 \pm 1333,67$ & $192.49 \pm 946.93$ & \\
\hline \multirow{2}{*}{$\begin{array}{l}\text { AST level (t3) } \\
\text { (U/L) }\end{array}$} & Min-max (median) & $8-15,026(59)$ & $12-12,688(55)$ & \multirow{2}{*}{${ }^{c} 0.467$} \\
\hline & Mean \pm SD & $613.53 \pm 1868,65$ & $625.27 \pm 1837,29$ & \\
\hline \multirow{2}{*}{$\begin{array}{l}\text { Difference between } \\
\text { AST level (t1-t2) } \\
(\mathrm{U} / \mathrm{L})\end{array}$} & Difference & $99.23 \pm 1294,29$ & $-7.63 \pm 1160,16$ & $0.039 *$ \\
\hline & $\mathrm{p}$ & $0.014^{*}$ & f $0.001 * *$ & - \\
\hline \multirow{2}{*}{$\begin{array}{l}\text { Difference between } \\
\text { AST level (t1-t3) } \\
(\mathrm{U} / \mathrm{L})\end{array}$} & Difference & $446.75 \pm 1868,19$ & $424.63 \pm 1649,89$ & ${ }^{\circ} 0.533$ \\
\hline & $\mathrm{p}$ & $0.005^{* *}$ & f 0.162 & - \\
\hline \multirow{2}{*}{$\begin{array}{l}\text { ALT level (t1) } \\
(\mathrm{U} / \mathrm{L})\end{array}$} & Min-max (median) & $3-7,174(29)$ & $2-4,772(53)$ & \multirow{2}{*}{$c 0.003^{* *}$} \\
\hline & Mean \pm SD & $116.91 \pm 538.64$ & $171.61 \pm 541.43$ & \\
\hline \multirow{2}{*}{$\begin{array}{l}\text { ALT level (t2) } \\
\text { (U/L) }\end{array}$} & Min-max (median) & $4-8,184(28)$ & $2-9,124(36)$ & \multirow{2}{*}{${ }^{\circ} 0.068$} \\
\hline & Mean \pm SD & $129.88 \pm 638.41$ & $242.83 \pm 1074,17$ & \\
\hline \multirow{2}{*}{$\begin{array}{l}\text { ALT level (t3) } \\
(\mathrm{U} / \mathrm{L})\end{array}$} & Min-max (median) & $4-4,076(37)$ & 2-9124 (50) & \multirow{2}{*}{${ }^{c} 0.067$} \\
\hline & Mean \pm SD & $224.57 \pm 592.22$ & $387 \pm 1174,11$ & \\
\hline \multirow{2}{*}{$\begin{array}{l}\text { Difference between } \\
\text { ALT level (t1-t2) } \\
(\mathrm{U} / \mathrm{L})\end{array}$} & Difference & $12.97 \pm 370.05$ & $71.22 \pm 1204,85$ & ${ }^{c} 0.090$ \\
\hline & $\mathrm{p}$ & f 0.217 & f $0.022^{*}$ & - \\
\hline \multirow{2}{*}{$\begin{array}{l}\text { Difference between } \\
\text { ALT level (t1-t3) } \\
(U / L)\end{array}$} & Difference & $107.66 \pm 628.99$ & $226.26 \pm 1014,91$ & ${ }^{\circ} 0.641$ \\
\hline & $\mathrm{P}$ & f0.001** & f 0.091 & - \\
\hline
\end{tabular}


[Glomerul filtration rate (GFR) between 30-60 mL/min] results in a 1.5-fold increase in Ctrough compared to patients with normal renal function. However, there is no evidence for its use among patients with GFR $<30 \mathrm{~mL} /$ $\min (14)$.
Organ toxicities that affect mortality were examined in our study, an increase was observed in AST and ALT levels in the favipiravir group, however this did not cause toxic hepatitis in the cases. There was no significant difference in the times of the CRRT need, urea and creatinine levels

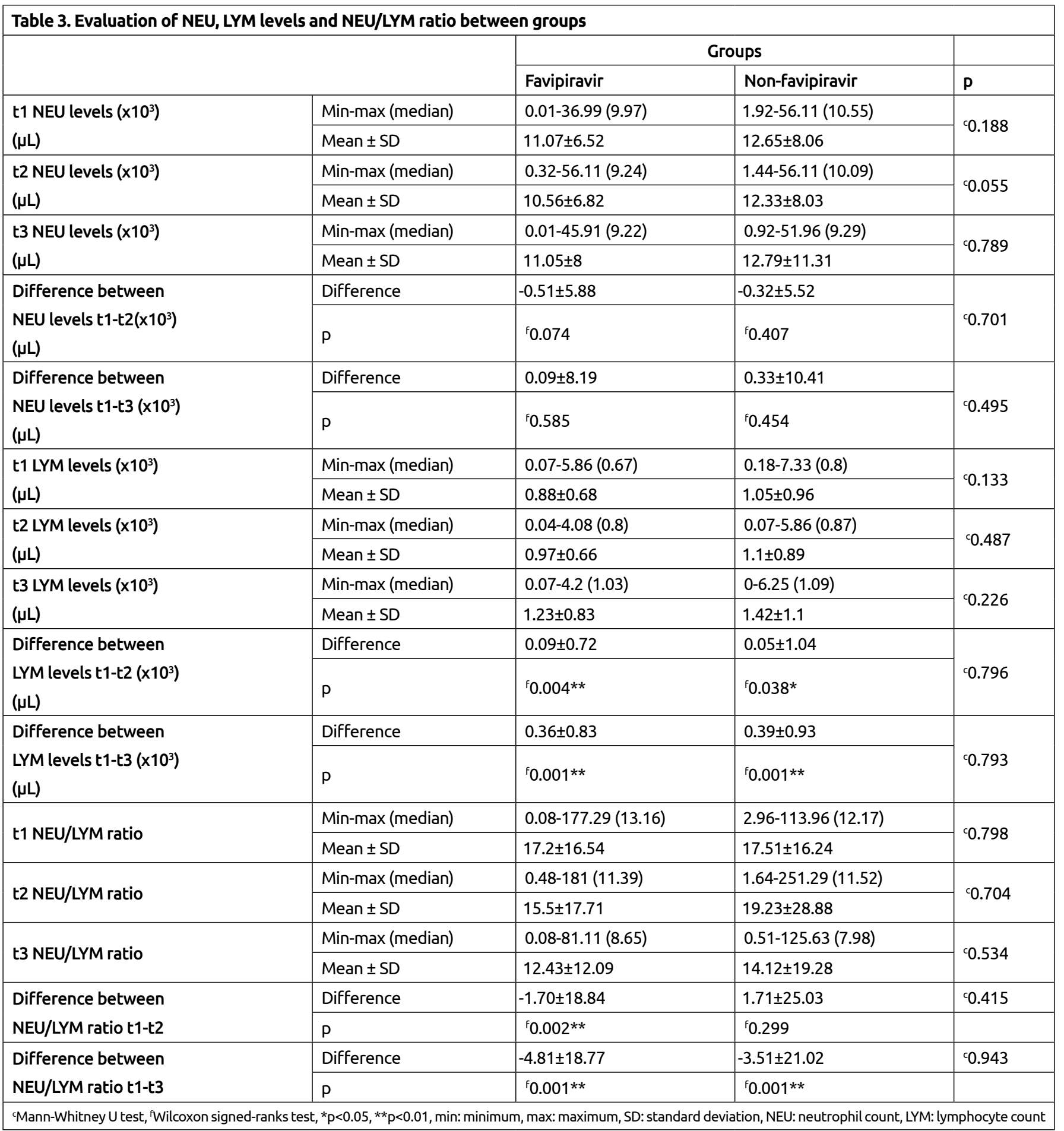


during follow-up between the groups. It was demonstrated that the cases included in our study had a similar clinical status in terms of known organ failure at the beginning of the intensive care unit.

In COVID-19 patients, coagulopathy with high D-dimer level and high fibrinogen level are frequently encountered. The group with high D-dimer values was found to be associated with higher mortality in a study (15). Increased D-dimer levels and normal fibrinogen levels were shown as laboratory evidence of COVID-19 disease in a study by Mucha et al. (14). In our study, no relationship was shown between D-dimer levels and mortality rates between these groups. Fibrinogen value was generally found to be normal or high.

Henry et al. (16) found that ferritin levels of deceased patients were higher than normal in a study they conducted. Likewise, in another study conducted in China, it was stated that it may be beneficial to monitor ferritin values in high-risk patients (17). In our study, ferritin values in both groups at the time of admission were also found to be higher than normal values. In our study, there was no significant difference in the follow-up of both groups in terms of acute phase reactants.

Deng et al. (18) compared non survival and survival patients in their study, they concluded that increased leukocyte count and decreased lymphocyte count were associated with mortality. Since there was no significant change in the presence of secondary infection between the groups, it suggests that the increased leukocyte count is not directly related to secondary infection. It has been determined that the cytokine release syndrome is associated with decreased lymphocyte level in new types of coronavirus patients (19). Significant reduction of T lymphocytes has been associated with mortality and is considered a poor prognosis factor and has been associated with disease severity in severely ill patients (20). When lymphocyte levels were evaluated in our study, the lymphocyte levels of the both groups were low at the time of hospitalization, a significant improvement was found in both groups during and at the end of the treatment. In a multicenter retrospective cohort study that included 60 inpatients and 42 outpatients, a total of 102 patients, NLR was calculated from hemogram parameters. As a result, advanced age, high LDH and high NLR values were considered as poor prognostic parameters in COVID19 patients and hospitalization was recommended to such patients (21). In our study, in the F group, the NLR was found to be lower than the initial value during the follow-up period and during discharge, however we could not find any effect of this situation on mortality.

It is difficult to conduct controlled studies in such a lifethreatening epidemic. Therefore, the study was planned as a retrospective observational study. It was unethical to allocate patients to receive different experimental drugs, and a randomization process was impossible. Therefore, we chose to conduct a before-after-designed study in which patients hospitalized in two consecutive periods were included in two groups, respectively. Lack of randomization, the absence of standard control groups and the additional use of glucocorticoids and lop/r made it difficult to evaluate the effect of favipiravir. The limitations of our study are that; it is retrospective and viral clearance was not examined.

\section{Conclusion}

There are many factors affecting mortality and morbidity in COVID-19 patients followed up in intensive care. In our study, no significant difference was found in terms of mortality and secondary outcome related favipiravir treatment in intensive care units. We determine that favipiravir treatment causes significant increases in liver enzymes. Therefore, we think that liver enzyme levels should be monitored more tightly in favipiravir treatment.

\section{Ethics}

Ethics Committee Approval: After the approval of the Turkish Ministry of Health Clinical Research Board; our study was approved by the Local Ethics Committee of the Bakırköy Dr. Sadi Konuk Training and Research Hospital with the decision number 2020/389 (date: 07.09.2020).

Informed Consent: Retrospective study.

Peer-review: Externally and internally peer-reviewed.

\section{Authorship Contributions}

Surgical and Medical Practices: K.Z.L.A., S.A., Concept: K.Z.L.A., R.Y., S.A., Y.T.S.., Design: R.Y., Y.T.Ş., Data Collection or Processing: K.Z.L.A., E.G., S.A., Analysis or Interpretation: E.G., S.A., Y.T.Ş., Literature Search: K.Z.L.A., R.Y., Writing: R.Y., Y.T.S..

Conflict of Interest: No conflict of interest was declared by the authors.

Financial Disclosure: The authors declared that this study received no financial support. 


\section{References}

1. Carlos WG, Dela Cruz CS, Cao B, Pasnick S, Jamil S. Novel Wuhan (2019-nCoV) Coronavirus. Am J Respir Crit Care Med 2020;201:P7-8.

2. Song $Y$, Zhang $M$, Yin $L$, Wang $K$, Zhou $Y$, Zhou $M$, et al. COVID-19 treatment: close to a cure? A rapid review of pharmacotherapies for the novel coronavirus (SARS-CoV-2). Int J Antimicrob Agents 2020;56:106080.

3. Treatment Guide for Adult Patients with Covid-19 compiled by the Scientific Committee (latest update 29/06/2021)

4. Furuta $Y$, Komeno $T$, Nakamura $T$. Favipiravir (T-705), a broad spectrum inhibitor of viral RNA polymerase. Proc Jpn Acad Ser B Phys Biol Sci 2017:93:449-63.

5. Dong L, Hu S, Gao J. Discovering drugs to treat coronavirus disease 2019 (COVID19). Drug Discov Ther 2020;14:58-60.

6. Wu C, Chen X, Cai Y, Xia J, Zhou X, Xu $\mathrm{S}$, et al. Risk Factors Associated With Acute Respiratory Distress Syndrome and Death in Patients With Coronavirus Disease 2019 Pneumonia in Wuhan, China. JAMA Intern Med 2020;180:93443.

7. Surviving Sepsis Campaign Guidelines on the Management of Adults With Coronavirus Disease 2019 (COVID19) in the ICU: First Update critical care medicine 2020. doi: 10.1097/ CCM.0000000000004899

8. ARDS Definition Task Force, Ranieri VM,
Rubenfeld GD, Thompson BT, Ferguson $N D$, Caldwell E, et al. Acute respiratory distress syndrome: the Berlin Definition. JAMA 2012;307:2526-33.

9. Cai Q, Yang M, Liu D, Chen J, Shu D, Xia J, et al. Experimental Treatment with Favipiravir for COVID-19: An Open-Label Control Study. Engineering (Beijing) 2020;6:1192-8.

10. Chan KS, Lai ST, Chu CM, Tsui E, Tam $\mathrm{CY}$, Wong MM, et al. Treatment of severe acute respiratory syndrome with lopinavir/ritonavir: a multicentre retrospective matched cohort study. Hong Kong Med J 2003;9:399-406.

11. Chen $C$, Huang J, Cheng $Z$, Zhang Y, Cheng Z, Wu J, et al. Favipiravir versus arbidol for COVID-19: a randomized clinical trial [online]. Medrxiv preprint 2020. doi:https://doi. org/10.1101/2020.03.17.20037432

12. Cao B, Wang $Y$, Wen D, Liu W, Wang J, Fan G, et al. A Trial of Lopinavir-Ritonavir in Adults Hospitalized with Severe Covid19. N Engl J Med 2020;382:1787-99.

13. Pilkington $V$, Pepperrell T, Hill A. A review of the safety of favipiravir - a potential treatment in the COVID-19 pandemic? J Virus Erad 2020;6:45-51.

14. Mucha SR, Dugar S, McCrae K, Joseph D, Bartholomew J, Sacha $\mathrm{GL}$, et al. Coagulopathy in COVID-19: Manifestations and management. Cleve Clin J Med 2020;87:461-8.

15. Zhang L, Yan X, Fan Q, Liu H, Liu X, Liu $Z$, et al. D-dimer levels on admission to predict in-hospital mortality in patients with Covid-19. J Thromb Haemost 2020;18:1324-9.

16. Henry BM, de Oliveira MHS, Benoit S, Plebani M, Lippi G. Hematologic, biochemical and immune biomarker abnormalities associated with severe illness and mortality in coronavirus disease 2019 (COVID-19): a metaanalysis. Clin Chem Lab Med 2020;58:1021-8.

17. Mehta P, McAuley DF, Brown M, Sanchez E, Tattersall RS, Manson JJ, et al. COVID19: consider cytokine storm syndromes and immunosuppression. Lancet 2020;395:1033-4.

18. Deng Y, Liu W, Liu K, Fang YY, Shang J, Zhou $L$, et al. Clinical characteristics of fatal and recovered cases of coronavirus disease 2019 in Wuhan, China: a retrospective study. Chin Med J (Engl) 2020;133:1261-7.

19. Lu R, Zhao X, Li J, Niu P, Yang B, Wu $\mathrm{H}$, et al. Genomic characterisation and epidemiology of 2019 novel coronavirus: implications for virus origins and receptor binding. Lancet 2020;395:565-74.

20. Xu B, Fan CY, Wang AL, Zou YL, Yu YH, $\mathrm{He} C$, et al. Suppressed T cell-mediated immunity in patients with COVID-19: A clinical retrospective study in Wuhan, China. J Infect 2020;81:e51-e60.

21. Li G, Xu F, Yin X, Wu N, Li Y, Zhang T, et al. Lactic dehydrogenase-lymphocyte ratio for predicting prognosis of severe COVID-19. Medicine (Baltimore) 2021;100:e24441. 